\title{
Vector-borne pathogens in dogs from Costa Rica: First molecular description of Babesia vogeli and Hepatozoon canis infections with a high prevalence of monocytic ehrlichiosis and the manifestations of co-infection
}

\author{
Alicia Rojas ${ }^{\mathrm{a}, *}$, Diana Rojas $^{\mathrm{a}}$, Víctor Montenegro ${ }^{\mathrm{b}}$, Ricardo Gutiérrez ${ }^{\mathrm{c}}$, \\ Daniel Yasur-Landau ${ }^{c}$, Gad Baneth ${ }^{c}$ \\ a Departamento de Parasitología, Centro de Investigación en Enfermedades Tropicales, Facultad de Microbiología, Universidad de Costa \\ Rica, P.O. Box 11501-2060, San José, Costa Rica \\ b Departamento de Parasitología, Escuela de Medicina Veterinaria, Universidad Nacional, P.O. Box 86-3000, Heredia, Costa Rica \\ ${ }^{c}$ Koret School of Veterinary Medicine, Hebrew University of Jerusalem, P.O. Box 12, Rehovot 76100, Israel
}

\section{A R T I C L E I N F O}

\section{Article history:}

Received 10 July 2013

Received in revised form 16 October 2013

Accepted 31 October 2013

\section{Keywords:}

Hepatozoon canis

Babesia vogeli

Ehrlichia canis

Rhipicephalus sanguineus

Amblyomma ovale

Costa Rica

\begin{abstract}
A B S T R A C T
Infection with canine vector-borne pathogens was evaluated in dogs from four different regions of Costa Rica by PCR. Demographic data, clinical signs, packed cell volume values, and the presence of tick infestation were recorded for each dog. Forty seven percent $(69 / 146)$ of the dogs were infected with at least one pathogen and $12 \%$ were co-infected with two pathogens. Ehrlichia canis was detected in 34\%, Anaplasma platys in 10\%, Babesia vogeli in $8 \%$, and Hepatozoon canis in $7.5 \%$ of the blood samples. No infection was detected with Leishmania spp. in blood, skin scrapings or conjunctival swabs. Thirty percent of the dogs presented at least one clinical sign compatible with vector-borne disease, and of those, $66 \%$ were infected with a pathogen. Subclinical infections were determined in $58 \%$ of the infected dogs including 82\% (9/11), 58\% (29/50), 42\% (5/12) and 36\% (5/14) of the dogs with $H$. canis, E. canis, B. vogeli and A. platys infections, respectively. A distinct relationship was found between infection and anemia. The mean PCV values were $34.4 \%$ in dogs with no infection, $31.5 \%$ in those who had a single infection and $23 \%$ in those with co-infection. Co-infected dogs had significantly lower PCV values compared to non-infected and singleinfected dogs $(p<0.0001)$. Thirty five percent $(51 / 146)$ of the dogs were infested with ticks, $82 \%$ of them were infested with Rhipicephalus sanguineus sensu lato and $18 \%$ with Amblyomma ovale. Dogs infected with A. platys, B. vogeli, or E. canis were significantly associated with $R$. sanguineus s.l. infestation $(p<0.029)$.

This is the first description of infections with B. vogeli and H. canis in Costa Rica as well as in Central America. The results of this study indicate that multiple vector-borne pathogens responsible for severe diseases infect dogs in Costa Rica and therefore, increased owner and veterinarian awareness are needed. Moreover, prevention of tick infestation is recommended to decrease the threat of these diseases to the canine population.
\end{abstract}

(c) 2013 Elsevier B.V. All rights reserved.
* Corresponding author at: Departamento de Parasitología, Centro de Investigación en Enfermedades Tropicales, Facultad de Microbiología, Universidad de Costa Rica, P.O. Box 11501-2060, San José, Costa Rica. Tel.: +506 25118645 .

E-mail addresses: anaalicia.rojas@ucr.ac.cr, alira.2212@gmail.com (A. Rojas).

\section{Introduction}

Vector-borne diseases are infections caused by viruses, bacteria, protozoa and helminths transmitted by arthropods such as mosquitoes, sandflies, ticks and fleas (Otranto and Dantas-Torres, 2010). Some of the vector-borne diseases are considered as emergent or re-emergent, having 
a major impact on animal and human health, as well as an economic burden (Harrus and Baneth, 2005; Yuasa et al., 2012). Dogs are affected by several of these pathogens, causing diseases such as leishmaniasis, monocytic ehrlichiosis, anaplasmosis, babesiosis, and hepatozoonosis (Otranto et al., 2009).

Vector-borne infections represent a diagnostic challenge as they usually cause non-specific signs and clinical manifestations which may vary according to the pathogen involved, parasitemia or bacteremia level, immune status and age of the dog (Baneth et al., 2012). The most common clinical findings are fever, lymphadenomegaly, pale mucous membranes, lethargy, scleral injection, anemia and petechiae. However, many affected dogs remain subclinically infected, complicating the therapeutic intervention and the control of the disease (Otranto et al., 2009). Moreover, subclinically-infected animals can play a role as reservoirs of pathogens.

Epidemiological studies are essential to describe the trends of infection with a particular pathogen and its vectors locally and regionally. Knowledge on vector-borne infections at the local level allows veterinary practitioners to recognize the pathogens that can affect their patients facilitating a prompt diagnosis and treatment (Baneth et al., 2012). Serological techniques have limited sensitivity and specificity which decrease their usefulness, however, molecular techniques allow the detection of pathogen DNA with high accuracy. Hence, molecular methods have become an excellent tool for epidemiological surveys worldwide (Tavares et al., 2011). Despite that, in Costa Rica, as well as in other countries of Central America, the status of dog infection with many canine pathogens is still vague. To date, no information has been available on infection with Babesia, Hepatozoon or Leishmania spp. in dogs in this country; and partial data on Ehrlichia canis and Anaplasma platys has been obtained only from a limited area of Costa Rica (Abrego et al., 2009; Romero et al., 2011). Furthermore, it is important to study the relationship between those infections, the dog's clinical status and presence of ectoparasite vectors, in order to have a wider epidemiological perspective.

The purpose of this study was to evaluate infection with vector-borne pathogens of dogs in four different regions from Costa Rica, and to associate the potential infectionstatus with other co-infecting pathogens, tick infestation, clinical manifestations and hematological findings.

\section{Materials and methods}

\subsection{Animals and samples}

Sampling of dogs was carried out in the regions of San Ramón, Alajuela $\left(10^{\circ} 05^{\prime} 14.28^{\prime \prime} \mathrm{N} 84^{\circ} 28^{\prime} 13.25^{\prime \prime} \mathrm{O}\right)$, Kéköldi, Limón (9 $\left.9^{\circ} 8^{\prime} 17.62^{\prime \prime} \mathrm{N} 82^{\circ} 47^{\prime} 48.53^{\prime \prime} \mathrm{O}\right)$, Liberia, Guanacaste $\left(10^{\circ} 38^{\prime} 57.56^{\prime \prime} \mathrm{N} 85^{\circ} 26^{\prime} 00.19^{\prime \prime} \mathrm{O}\right)$ and Chomes, Puntarenas $\left(10^{\circ} 3^{\prime} 56.16^{\prime \prime} \mathrm{N} 84^{\circ} 57^{\prime} 47.38^{\prime \prime} \mathrm{O}\right)$ (Fig. 1), in Costa Rica during the rainy season (July, August and September) of 2012. A questionnaire was filled for each dog with information on sex, age, and results of physical examination. Blood was drawn by puncture of the cephalic vein and collected in EDTA tubes. A conjunctival sterile-swab was taken from each eye and placed in a sterile microcentrifuge tube. A skin scraping of the dog's left ear was taken with a sterile blade and kept in a sterile tube. The samples were transported at $4{ }^{\circ} \mathrm{C}$ to the laboratory and stored at $-20^{\circ} \mathrm{C}$ until further analysis. Additionally, presence of tick infestation on dogs was assessed by visual inspection and combing, and tick specimens were collected and kept in sterile tubes. Taxonomic identification of ticks was determined by observation of morphological characteristics according to the guide of Barros-Battesti et al. (2006).

The packed cell volume (PCV) was measured from the EDTA blood samples by glass capillary centrifugation. The dogs sampled were divided into three groups according to PCV values: group 1 (7-24\%), group 2(25-34\%) and group 3 (35-50\%). Dogs in group 3 were the only ones with a normal PCV which ranges between 35 and 55\%.

The project was approved by the Inter-Institutional Committee for the Care and Use of Animals (CICUA), Universidad de Costa Rica.

\subsection{DNA extraction}

DNA from EDTA blood samples and skin scrapes was extracted with commercial kits (Illustra Blood Genomic Prep Mini Spin Kit and Illustra Tissue and Cells MiniSpin Prep, GE Healthcare, Buckinghamshire, United Kingdom), following the manufacturer recommendations. DNA from conjunctival swabs was extracted with a phenol:chloroform:isoamylic alcohol protocol as described previously (Strauss-Ayali et al., 2004).

\subsection{Conventional and real-time PCR for Ehrlichia, Anaplasma, Hepatozoon, Babesia, and Leishmania spp.}

Blood samples were screened for the presence of Ehrlichia, Anaplasma, Babesia, and Hepatozoon spp. by conventional PCR. PCR was performed using the Syntezza PCR-Ready ${ }^{\mathrm{TM}}$ High Specificity (Syntezza Bioscience, Israel) kit tubes with $20 \mu$ l of PCR grade water (Sigma, St. Louis, United States), $1 \mu$ l of $500 \mathrm{nM}$ of each primer, and $3 \mu \mathrm{l}$ of the respective DNA. For Hepatozoon spp. detection, primers HEP-F and HEP-R (Inokuma et al., 2002) which amplify a fragment of approximately 666 bp of the $18 S$ gene of ribosomal DNA were employed, following conditions described by Otranto et al. (2011). The primers Piroplasmid-F and Piroplasmid-R were employed to detect a 400 bp fragment of the $18 \mathrm{~S}$ ribosomal DNA of piroplasmid such as Babesia and Theileria spp. as described previously (Tabar et al., 2008). Finally, primers EHR-16SD and EHR-16SR (Parola et al., 2000) were used to amplify a $345 \mathrm{bp}$ fragment of the $16 S$ gene of Ehrlichia and Anaplasma spp. and the reaction protocol was modified from Parola et al. (2000) as follows: $95^{\circ} \mathrm{C}$ for $5 \mathrm{~min}, 45$ cycles of $94^{\circ} \mathrm{C}$ for $30 \mathrm{~s}, 59^{\circ} \mathrm{C}$ for $30 \mathrm{~s}$ and $72{ }^{\circ} \mathrm{C}$ for $60 \mathrm{~s}$; and a final elongation at $72{ }^{\circ} \mathrm{C}$ for $5 \mathrm{~min}$. All amplicons were visualized in ethidium-bromide stained $2 \%$ agarose gels.

Specific-pathogen real-time assays were performed for the detection of E. canis, Babesia vogeli, and Leishmania spp. in blood samples. In addition, Leishmania spp. DNA was further screened in the conjunctival swabs and skin scrapes. Samples for real time PCRs were prepared in a final 


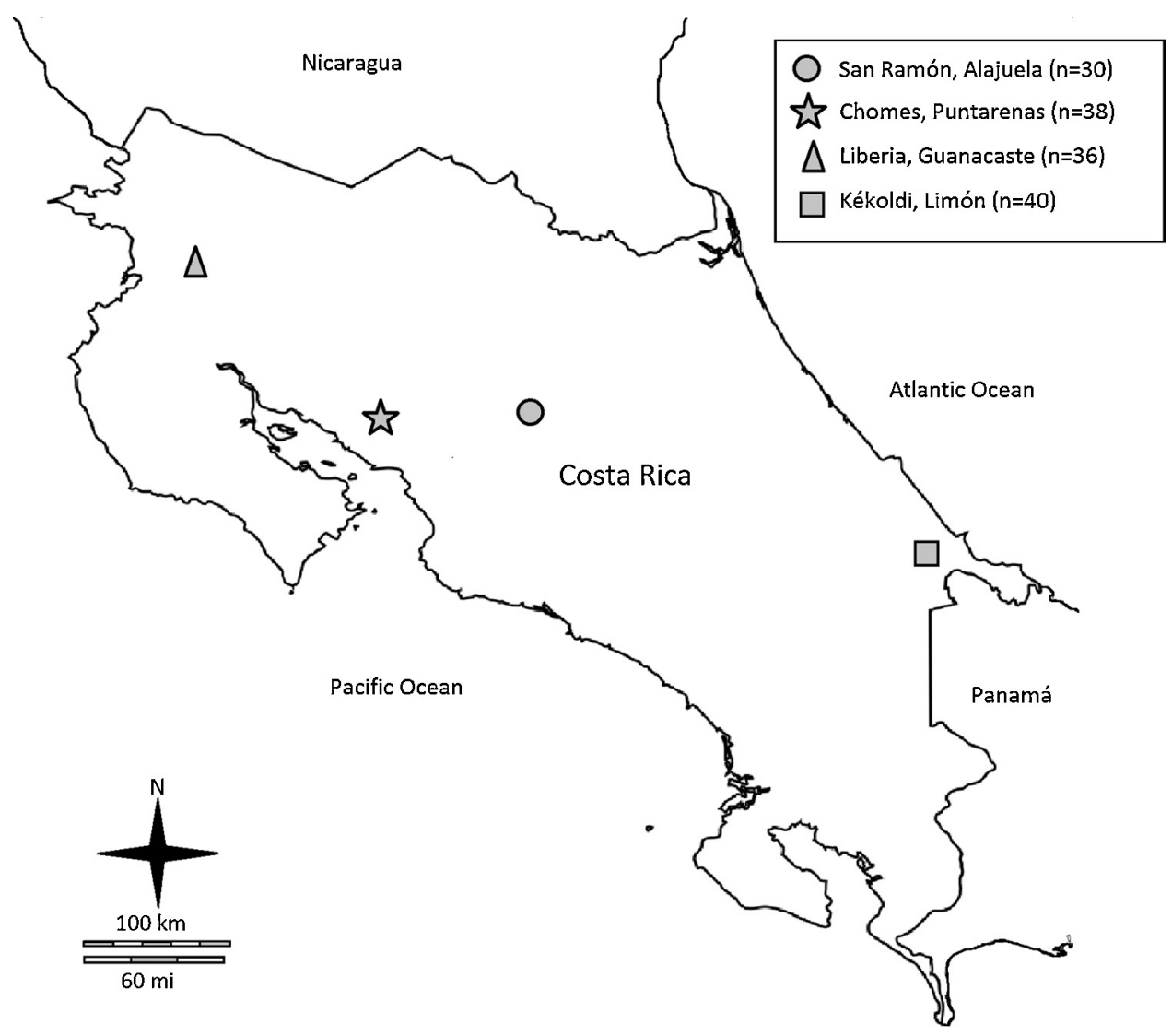

Fig. 1. Map of Costa Rica showing the locations where dog samples were collected. The number of animals tested in each region is annotated in parenthesis. The template map was modified from: www.d-maps.com.

volume of $20 \mu \mathrm{l}$ with $0.6 \mu \mathrm{l}$ SYTO-9 (Invitrogen, Carlsbad, United States), $10 \mu$ l of Maxima Hot Start PCR Master Mix $2 \times$ (Thermo Fisher Scientific Inc., Surrey, UK), $4.4 \mu \mathrm{l}$ PCR grade water (Sigma, St. Louis, USA), $1 \mu$ l of each primer and $3 \mu \mathrm{l}$ of DNA. Reactions were performed by a Rotor Gene $6000^{\mathrm{TM}}$ cycler (Corbet, Sydney, Australia). All real-time PCR runs included a non-template control (NTC) with PCR grade water, DNA from a specific-pathogen-free negative dog and the respective pathogen DNA, as controls. Leishmania spp. real-time PCR detection was assessed using primers ITS219F and ITS-219R (Talmi-Frank et al., 2010) which amplify a 265-288 bp fragment within the Leishmania ribosomal operon internal transcribed spacer1 (ITS1). The protocol was modified by performing an initial hold of $4 \mathrm{~min}$ at $95^{\circ} \mathrm{C}$ and 40 cycles of 5 s at $95^{\circ} \mathrm{C}, 30$ s at $59^{\circ} \mathrm{C}$ and $1 \mathrm{~s}$ at $72^{\circ} \mathrm{C}$. The melt curve was built from 60 to $95^{\circ} \mathrm{C}, 1^{\circ} \mathrm{C} / \mathrm{s}$, followed by a hybridization step $\left(90-50^{\circ} \mathrm{C}\right)$. A high resolution melt-curve was performed from 75 to $90^{\circ} \mathrm{C}$ at $0.4^{\circ} \mathrm{C} / \mathrm{s}$. Primers EHR16S fwd and EHR16S rev (Peleg et al., 2010) at a concentration of $400 \mathrm{nM}$ were used to detect E. canis. The real-time PCR conditions were: $95^{\circ} \mathrm{C}$ for $4 \mathrm{~min}, 45$ cycles of $95^{\circ} \mathrm{C}$ for $15 \mathrm{~s}$, $59^{\circ} \mathrm{C}$ for $30 \mathrm{~s}$ and $72^{\circ} \mathrm{C}$ for $30 \mathrm{~s}$. The melt curve was measured from $65^{\circ} \mathrm{C}$ to $95^{\circ} \mathrm{C}$ with a raise of $1^{\circ} \mathrm{C} / \mathrm{s}$. For $B$. vogeli detection, a fragment of $90 \mathrm{bp}$ length of the $h s p 70$ gene was amplified with primers B.c hsp70-F and B.c hsp70-R according to the conditions described by Peleg et al. (2010). This specific reaction was used to detect co-infections with
Babesia spp. and Hepatozoon canis that may not be evident by the means of the conventional PCRs described above.

\subsection{Sequencing analysis}

All positive amplicons were purified (EXO-Sap, New England Biolabs Inc., Ipswich, United States) and sequenced using the BigDye Terminator cycle from Applied Biosystems ABI3700 DNA Analyzer, and the ABI' Data Collection and Sequence Analysis software (ABI, Carlsbad, United States). Samples were considered positive to a pathogen in this study only if they were positive by PCR and if sequencing of the amplicon indicated that the closest GenBank accession was at least $97 \%$ identical to the identified organism. Data was analyzed with the Chromas Lite Version 2.01 software and compared to the data available from GenBank using the BLASTN 2.2.26 program (http://www.ncbi. nlm.nih.gov/BLAST).

\subsection{Statistical analysis}

The frequency distribution for all variables was calculated and the percentages of the identified categories were obtained. To estimate the potential association between nominal variables, the Chi-square or Fisher's exact tests were applied. The Chi-square test was employed when more than $80 \%$ of the expected frequencies of cells were 
higher than 5 units, and the Fisher's exact test was used when more than $20 \%$ of the expected frequencies of cells were lower than 5 units. The Phi coefficient test was performed to measure the strength of association between two nominal variables. The Spearman' ranks correlation coefficient was calculated to correlate PCV level groups and infection status. To evaluate differences between mean PCV values and infection status, as well as age mean values and dog' infection status, two-tailed T-test was performed. The hypothesis tests were analyzed under the hypothesis of null independence. Significance was determined with $p<0.05$. The Bonferroni correction was applied in cases where multiple comparisons were performed. Data was analyzed using the IBM SPSS Statistics 20 software.

\section{Results}

\subsection{Pathogen DNA detection}

Blood, skin scrapes and conjunctival swabs samples from a total of 146 dogs from the four different geographical zones were analyzed (Fig. 1). Forty seven percent (69/146; 95\% C.I.: $39.0-55.7 \%$ ) of the dogs were infected with at least one of the pathogens. Thirty four percent (50/146; 95\% C.I.: $26.6-42.6 \%)$ of the dogs were positive for $E$. canis, 10\% (14/146; 95\% C.I.: 5.3-15.6\%) for A. platys, 8\% (12/146; 95\% C.I.: 4.3-13.9\%) for B. vogeli, and 7.5\% (11/146; 95\% C.I.: $3.8-13.1 \%)$ for $H$. canis. There were no blood samples positive for Theileria spp. and Leishmania spp.-DNA was not detected in any blood, skin or swab samples. Additionally, co-infections with two vector-borne pathogens were found in $12.3 \%$ (18/146; 95\% C.I.: $7.5-18.9 \%)$ of the dogs representing 26\% (18/69; 95\% C.I.: $16.2-38.1)$ of the infected dogs. The co-infections detected included $E$. canis and B. vogeli in 8/18 dogs (44\%; 95\% C.I.: 21.5-69.2\%), followed by E. canis and A. platys in 4/18 (22\%; 95\% C.I.: 6.4-47.6\%), E. canis and $H$. canis in 3/18 (17\%, 95\% C.I.: 3.6-41.4\%), A. platys and B. vogeli in $2 / 18(11 \%, 95 \%$ C.I.: $1.4-34.7 \%)$ and finally $A$. platys and H. canis in one dog (6\%; 95\% C.I.: 0.1-27.3\%). The GenBank accession numbers with the closest match to the pathogen DNA sequences found in this study are shown in Table 1.

The presence of the pathogens detected varied according to the geographic location (Table 1 ). The distribution of $E$. canis was higher in Liberia and Chomes compared to San Ramón and Kéköldi, and a significant difference was observed between these prevalence rates (Fisher's exact test, all $p<0.001)$. A. platys was present only in Chomes and Liberia, and it was equally distributed in both places (Fisher's exact test, $p=1.000$ ). Moreover, $B$. vogeli distribution was significantly different in the different geographic locations (Fisher's exact test, $p=0.005$ ), with a higher prevalence of infection found in Chomes. H. canis was found in all regions and no significant difference in the distribution was detected between locations.

\subsection{Pathogen infection vs. clinical signs}

Thirty percent (44/146; 95\% C.I.: $22.8-38.3 \%$ ) of the dogs presented at least one of the listed clinical signs, and of those, $66 \%$ (29/44; 95\% C.I.: 50.1-79.5\%) were infected with at least one the pathogens (Table 2). Of the single-infection cases, $71 \%$ (5/7; 95\% C.I.: 29.0-96.3\%) of A. platys, $37 \%$ (13/35; 95\% C.I.: 21.5-55.1\%) of E. canis and 8\% (1/12; 95\% C.I.: $0.2-38.5 \%$ ) of $B$. vogeli infections were associated with at least one of the listed clinical signs. Two of the 11 cases of $H$. canis-infection presented clinical signs, but both were also infected with $E$. canis. There was a significant association between infection with A. platys and lethargy (Fisher's exact test, $p=0.003$; Phi $=0.31, p=0.0002$ ), fever (Fisher's exact test, $p=0.03$; Phi $=0.23, p=0.006$ ), poor body condition (Fisher's exact test, $p=0.042$; Phi $=0.21, p=0.01$ ) and scleral injection (Fisher's exact test, $p=0.046$; Phi $=0.23$, $p=0.05)$. E. canis infection was associated with fever (Fisher's exact test, $p=0.020$; Phi $=0.21 ; p=0.01$ ), alopecia (Chi-square test, $\chi^{2}=7.9$, d.f. $=1, p=0.005$; Phi $=0.23$, $p=0.005$ ), and pale mucous membranes (Chi-square test, $\chi^{2}=4.7$, d.f. $=1 ; p=0.029$; Phi $=0.18, p=0.03$ ).

Subclinical infections were defined as infections with pathogens without manifestation of any clinical signs. These infections were determined in 58\% (40/69; 95\% C.I.: 45.5-69.8\%) of the infected dogs. Consequently, 82\% (9/11), $58 \%$ (29/50), 42\% (5/12) and 36\% (5/14) of the dogs with $H$. canis, E. canis, B. vogeli and A. platys infections, respectively, did not present any clinical signs.

\subsection{Pathogen infection vs. packed cell volume (PCV) values}

A significant negative correlation was found between PCV level groups and infection (none, single infection and co-infection) (Spearman's ranks correlation, $r_{\mathrm{s}}=-0.38$, $p<0.0001$ ) (Fig. 2). The prevalence of infection was $76 \%$ (19/25; 95\% C.I.: 54.9-90.6\%) in group 1 (PCV 7-24\%), 51\% (33/65; 95\% C.I.: 38.1-63.4\%) in group 2 (PCV 25-34\%), and 31\% (17/55; 95\% C.I.:19.2-44.8\%) in group 3 (PCV 35-50\%). Furthermore, co-infection was found more frequently in dogs of group 1 than in group 2. Dogs from group 3 had a lower co-infection prevalence than group 1 and 2 dogs.

Co-infected dogs had lower PCV values compared to non-infected and single-infected dogs. The mean PCV values were $34.4 \pm 0.8 \%$ in dogs with no infection, $31.5 \pm 1 \%$ in those who had a single infection and $23 \pm 1.5 \%$ in those with co-infection. The latter group was significantly different from the former two (two-tailed $t$-test, both $p<0.0001$ ). Moreover, lower PCV levels were observed in dogs with $E$. canis (31.1\%), B. vogeli (29\%), and A. platys (27.3\%) infections when compared to non-infected dogs (two-tailed $t$-test, all $p<0.05$ ).

\subsection{Pathogen infection vs. age}

Dog ages ranged from 0.5 to 12 years. Co-infected dogs were significantly younger than uninfected dogs or those with a single infection. The mean age of dogs infected with two pathogens $(1.7 \pm 0.30$ years, $n=18)$ was significantly lower than the mean ages of dogs with no pathogen infection ( $3.2 \pm 0.3$ years, $n=76$ ) or those with only one pathogen detected $(3.4 \pm 0.4$ years, $n=51$ ) (twotailed $t$-test, $t=-2.3$, d.f. $=92, p=0.021$ and $t=-2.5$, d.f. $=67$, $p=0.015$, respectively). Nevertheless, an association could 
Table 1

Detection of vector-borne pathogens in 146 dogs from 4 different regions of Costa Rica. All the results were obtained from blood samples, except for the detection of Leishmania spp., carried out in blood, skin scrapes and conjuctival swabs.

\begin{tabular}{|c|c|c|c|c|c|c|}
\hline \multirow[t]{2}{*}{ Pathogen } & \multicolumn{4}{|c|}{$\begin{array}{l}\text { Total number of dogs infected with each pathogen } \\
\text { per region (\% of the total dogs infected with the } \\
\text { pathogen) }\end{array}$} & \multirow[t]{2}{*}{$\begin{array}{l}\text { Total number of dogs } \\
\text { infected with each } \\
\text { pathogen (\% of total dogs) }\end{array}$} & \multirow[t]{2}{*}{$\begin{array}{l}\text { Identity to GenBank accession } \\
\text { number (number of dogs; \% } \\
\text { sequence identity) }\end{array}$} \\
\hline & $\begin{array}{l}\text { Chomes } \\
(n=38)\end{array}$ & $\begin{array}{l}\text { Liberia } \\
(n=36)\end{array}$ & $\begin{array}{l}\text { San } \\
\text { Ramón } \\
(n=30)\end{array}$ & $\begin{array}{l}\text { Kéköldi } \\
(n=42)\end{array}$ & & \\
\hline Ehrlichia canis & $22(44 \%)$ & $21(42 \%)$ & $5(10 \%)$ & $2(4 \%)$ & $50(34.2 \%)$ & $\begin{array}{l}\text { JQ976664.1 (37; 98\%) } \\
\text { AB723711.1 (13; 99\%) }\end{array}$ \\
\hline Anaplasma platys & $7(50 \%)$ & $7(50 \%)$ & 0 & 0 & $14(10 \%)$ & $\begin{array}{l}\text { JQ894779.2 }(7 ; 98 \%) \\
\text { JX261979.1 }(4 ; 99 \%) \\
\text { JQ976642.1 }(3 ; 98 \%)\end{array}$ \\
\hline Babesia vogeli & $8(67 \%)$ & $3(25 \%)$ & 0 & $1(8 \%)$ & $12(8 \%)$ & $\begin{array}{l}\text { JX304677.1 (11; 98\%) } \\
\text { JX112785.1 (1;99\%) }\end{array}$ \\
\hline Hepatozoon canis & $2(18 \%)$ & $2(18 \%)$ & $6(55 \%)$ & $1(9 \%)$ & $11(8 \%)$ & $\begin{array}{l}\text { AY150067.2 (9; 99\%) } \\
\text { DQ869309.1 (2; 100\%) }\end{array}$ \\
\hline Leishmania spp. & 0 & 0 & 0 & 0 & 0 & N.D. \\
\hline
\end{tabular}

N.D.: not determined.

not be established between age and the presence of a particular pathogen.

\subsection{Pathogen infection vs. sex}

No association was found between sex and presence of infection or co-infection (Chi-square test, $\chi^{2}=2.1$, d.f. $=2, p=0.343$ ). Furthermore, no relationship was found between sex and the prevalence of each of the studied pathogens (Chi-square test, all $p>0.238$ ).

\subsection{Tick infestation}

A total of 425 ticks were collected from 35\% (51/146; 95\% C.I.: 27.2-43.2\%) of the dogs. Ticks were classified as Rhipicephalus sanguineus sensu lato and Amblyomma ovale. Of the 51 dogs with ticks, 82\% (42/51; 95\% C.I.: $69.1-91.6 \%)$ were infested with $R$. sanguineus s.l. and $18 \%$
(9/51; 95\% C.I.: 8.4-30.9\%) with A. ovale. $R$. sanguineus s.l. was found in the regions of Chomes, Liberia and Kéköldi; and $A$. ovale was identified only in dogs from Kéköldi. One dog from Chomes was co-infested with $R$. sanguineus s.l. and an Amblyomma sp. nymph which could not be taxonomically identified. Ticks were not observed in the dogs from San Ramón. The prevalence of dog tick infestation in Chomes and Liberia were higher than in Kéköldi, and their distributions were significantly different (Chi-square test, $\chi^{2}=13.4$, d.f. $=1 p<0.0001$ and $\chi^{2}=4.7$, d.f. $=1, p=0.03$, respectively). There was a strong association between tick infestation and pathogen infection in the different geographic locations (Chi-square test, $\chi^{2}=37.1$, d.f. $=3, p<0.0001$; Phi $=0.50, p<0.0001$ ).

An association between infestation with $R$. sanguineus s.l. and single infection or co-infection was observed (Chi-square test, $\chi^{2}=28.5$, d.f. $=2, p<0.0001$; Phi $=0.44$, $p<0.0001$ ). Sixty four percent of the dogs infected with

Table 2

Clinical signs recorded for 146 dogs from different regions of Costa Rica and their association with infection with at least one of the following pathogens: Ehrlichia canis, Anaplasma platys, Babesia vogeli or Hepatozoon canis. The presence of clinical signs in the total population of sampled dogs was compared to its presence among the dogs with confirmed infection. The presence of a significant relationship $(p<0.05)$ between demonstrating each clinical sign and the presence of a vector-borne infection is indicated.

\begin{tabular}{lcc}
\hline Clinical sign & $\begin{array}{l}\text { Number of dogs with the clinical sign (\% of } \\
\text { total number of dogs) }\end{array}$ & $\begin{array}{l}\text { Number of dogs with the clinical sign and infection } \\
\text { with at least one of the vector-borne pathogens (\% of } \\
\text { total number of dogs presenting the clinical sign) }\end{array}$ \\
\hline $\begin{array}{l}\text { Pale mucous } \\
\text { membranes }\end{array}$ & $22(15.1 \%)$ & $14(58 \%)$ \\
Alopecia & $17(11.6 \%)$ & $13(72 \%)^{*}$ \\
Lethargy & $13(8.9 \%)$ & $10(76.9 \%)^{*}$ \\
Poor body condition & $9(6.2 \%)$ & $7(70 \%)$ \\
Fever $\left(>39.5{ }^{\circ} \mathrm{C}\right)$ & $8(5.5 \%)$ & $7(87.5 \%)^{*}$ \\
Scleral injection & $4(2.7 \%)$ & $4(100 \%)^{*}$ \\
Cough & $3(2.1 \%)$ & $2(66.7 \%)$ \\
Purulent nasal & $2(1.4 \%)$ & $2(100 \%)$ \\
discharge & $1(0.7 \%)$ & $1(100 \%)$ \\
Ataxia & $1(0.7 \%)$ & $1(100 \%)$ \\
Dyspnea & $1(0.7 \%)$ & $1(100 \%)$ \\
Lymphadenomegaly & $1(0.7 \%)$ & $1(100 \%)$ \\
Petechiae & & \\
\hline
\end{tabular}

\footnotetext{
Chi square test, $p<0.05$.
} 


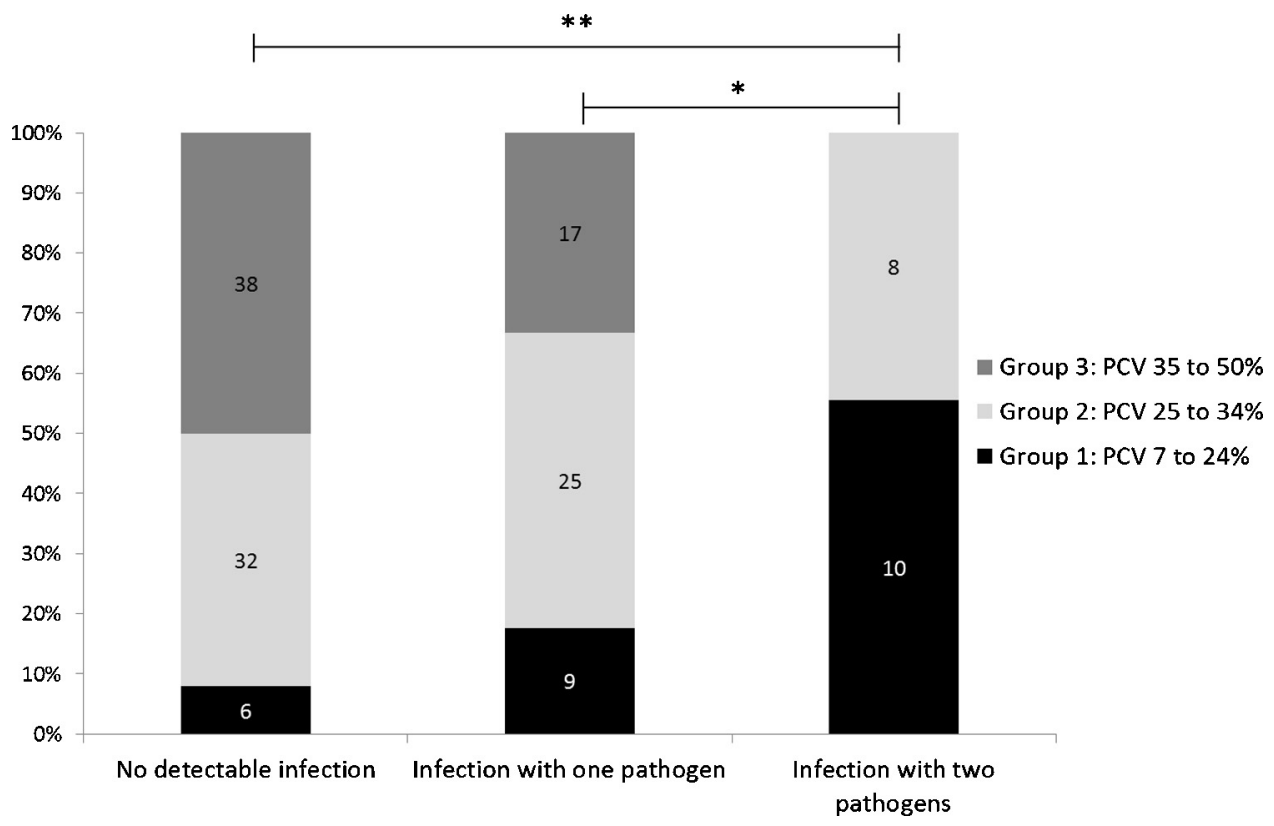

Fig. 2. Relationship between the packed cell volume (PCV) of 146 dogs and presence of infection with vector-borne pathogens detected in the study. Distribution adjusted to $100 \%$ of dogs with no detectable infection, single and co-infection according to their PCV value. The number of dogs within each category is indicated in each column. A value of $p<0.05$ was considered significant.

A. platys, $58 \%$ with B. vogeli, and $54 \%$ with E. canis were infested with $R$. sanguineus s.l. Consequently, there was a significant association between infection with either of these pathogens and infestation with $R$. sanguineus s.l. (Chisquare test, all $p<0.029$ ). No infection was found in dogs infested with $A$. ovale, except for one of these nine dogs which was infected with $H$. canis.

\section{Discussion}

Canine vector-borne diseases are usually distributed geographically in close relationship with the presence of their vector hosts. Climate change, increased travel, transport and globalization, have facilitated the spread of these infections into previously unaffected regions (Harrus and Baneth, 2005). Therefore, it is important to study the presence of these infections in order to know what diseases can be expected in each country or region. This study constitutes the first report of $B$. vogeli and $H$. canis infection in dogs in Costa Rica and in Central America. Moreover, a high prevalence of $E$. canis and $A$. platys infections was detected in dogs, and infection and co-infections with these vectorborne pathogens were clearly associated with anemia and clinical abnormalities such as fever.

B. vogeli detected in $8.2 \%$ of the Costa-Rican dogs in this study, has been shown to infect dogs in both South and North America (Birkenheuer et al., 2005; Criado-Fornelio et al., 2007). Surveys from Colombia (Vargas-Hernández et al., 2012) and Venezuela (Criado-Fornelio et al., 2007) reported infections with $B$. vogeli in $5.5 \%$ and $2.2 \%$ of the dogs studied, respectively. Furthermore, a study conducted in three areas of Brazil reported $9.9 \%$ of positivity to B. vogeli in dogs during the dry season and $10.8 \%$ in the rainy season (Costa-Júnior et al., 2012). The detection of B. vogeli infection in Costa Rican dogs was not surprising due to the presence of its vector $R$. sanguineus s.l. in Costa Rica, as demonstrated in the present study and previously observed also by Troyo et al. (2012). Our molecular assays were able also to detect other piroplasmid species, such as Theileria spp., however, these were not found in the surveyed dogs. Fifty eight percent of the dogs with $B$. vogeli infection were found infested with ticks. B. vogeli infection in the absence of tick infestation may be explained by the drop-off rhythm of $R$. sanguineus s.l. (Dantas-Torres, 2010) or by the fact that $B$. vogeli infection is chronic and dogs may have been infected long before the survey. Fifty eight percent of the studied dogs with $B$. vogeli infection showed clinical manifestations in accordance to the mild to moderate clinical disease that this parasite may cause (Solano-Gallego and Baneth, 2011). All of the dogs infected with $B$. vogeli presented anemia, which is characteristic of this infection that typically involves erythrocyte destruction (Solano-Gallego and Baneth, 2011).

H. canis-infection was found in $7.5 \%$ of the sampled dogs. A higher prevalence of $H$. canis has been reported in studies from Colombia (Vargas-Hernández et al., 2012) and Venezuela (Criado-Fornelio et al., 2007), with $31.8 \%$ and $44 \%$ prevalence of infection, respectively. Infection with $H$. canis, as in the case of $B$. vogeli-infection, can be explained by the widespread prevalence of its main vector $R$. sanguineus s.l. in Costa Rica. No other Hepatozoon spp. were detected in our study, supporting the notion that canine $H$. americanum infection is restricted at the moment to the United States and has not reached Costa Rica (Baneth, 2011). Infection with $H$. canis has been mostly associated with subclinical to mild infection (Baneth, 2011), which is in agreement with the lack of clinical signs found in dogs infected only with $H$. canis in the present study. 
This study has indicated that there is a high prevalence of infection with $E$. canis in dogs within the studied geographical areas from Costa Rica since more than a third of the studied dogs were positive for this pathogen. High E. canis-prevalences of infection of $40.6 \%$ and $31 \%$ by molecular detection have been reported from Colombia (Vargas-Hernández et al., 2012), and Venezuela (Unver et al., 2001), respectively. A previous report by Romero et al. (2011) found a $47.7 \%$ prevalence of infection among 310 dogs with suspected monocytic ehrlichiosis from a single region of Costa Rica. The lower prevalence of infection obtained in the present study may be explained by the sampling of dogs that were not suspected for disease, and also by sampling from different regions in Costa Rica, where prevalence of infection may be different. It is important to mention that a zoonotic $E$. canis strain has been described in Venezuela (Perez et al., 2006) and thus further studies are needed to evaluate the relatedness of the strains of $E$. canis circulating in Costa Rica and other countries in the American continent to this zoonotic strain. The association found between $E$. canis infection and the presence of clinical abnormalities such as fever and anemia is in agreement with previous descriptions of this disease (Harrus and Waner, 2011).

Anaplasma platys was detected in $9.6 \%$ of the dog samples which is a higher prevalence of infection than $6.3 \%$ found in a previous report of this rickettsial pathogen in dogs from Costa Rica (Abrego et al., 2009). Interestingly, the dogs in the present study found infected only with $A$. platys presented lethargy, poor body condition and anemia. The presence of anemia in these dogs differed from findings described in a study conducted with dogs experimentally infected with $A$. platys and E. canis (Gaunt et al., 2010) in which dogs infected only with A. platys were not anemic and had normal hematocrit values. The presence of anemia in dogs infected with A. platys from Costa Rica can possibly be explained by infection with a more virulent strain of this rickettsia circulating in Costa Rica, or by some other undetected infection or medical condition in these infected dogs. A. platys infection associated with more severe clinical manifestations to those reported in the USA has been described in Greece and Israel and suspected to be caused by more virulent strains of this rickettsia (Harrus et al., 1997; Kontos et al., 1991).

The present study has also determined that co-infection in dogs infected with tick-borne pathogens including $E$. canis, B. vogeli, A. platys and $H$. canis is associated with more severe anemia. This highlights the consequences of co-infection and the importance of screening for more than one pathogen in the veterinary practice, hence an efficient treatment can be administered. The fact that co-infected dogs were significantly younger than uninfected dogs or those with a single infection may be explained by a greater sensitivity of young dogs to tick-borne infections and a possible resistance developed in older dogs who may have survived exposure to these pathogens at an earlier age (Otranto et al., 2010).

No Leishmania spp. infection was detected in the blood, skin and conjunctival swabs from the sampled dogs in this study. Leishmania infantum, the etiological agent of canine leishmaniasis and human visceral leishmaniasis, has been detected sporadically in Costa Rica. A case of canine leishmaniasis was reported three decades ago in a dog imported from Spain (Mendoza et al., 1983). In addition, in 1999 a case of visceral leishmaniasis in a child was detected for the first time in the region of Liberia, Guanacaste, which was sampled in this study (Carrillo et al., 1999). Costa Rica is endemic for cutaneous leishmaniasis caused by L. panamensis and L. braziliensis in humans with a reported incidence of 41 per 100,000 inhabitants in 2007 (Jaramillo-Antillón et al., 2009). Nevertheless, the absence of Leishmania spp. in the sampled dogs suggests that dogs are not an important host of this protozoon in Costa Rica. However, dogs and other animals from other regions of the country must be tested, in order to support this assumption.

This study detected the tick A. ovale only on dogs from the Caribbean coast of Costa Rica, while $R$. sanguineus s.l. was found in our study to be widespread and present on both coasts. This could be due to a difference in the environmental conditions between the coasts. However, sampling of more regions is necessary in order to sustain this finding, since this tick was found on both coasts in Panamá (Bermúdez and Miranda, 2011). A. ovale has been shown to be a vector of $H$. canis in Brazil (Rubini et al., 2009) but has not been associated with other vector-borne infections of dogs. This explains why $R$. sanguineus s.l. and not $A$. ovale was associated with $E$. canis, $B$. vogeli and $A$. platys in the present study. Although $A$. platys has not been proven to be transmitted by $R$. sanguineus s.l., it has been suspected to be its most likely vector (Costa-Junior et al., 2013).

\section{Conclusions}

The present study demonstrated that dogs in Costa Rica are frequent hosts of vector-borne pathogens and that infection and co-infection are associated with severe anemia and clinical manifestations. The confirmation of canine babesiosis and hepatozoonosis, and the high prevalence of canine ehrlichiosis and thrombocytic anaplasmosis in Costa Rica should be brought to the attention of veterinarians and dog owners in order to decrease the burden of these diseases among dogs.

\section{Acknowledgements}

The authors thank Drs. Osnat Eyal and Yaarit Biala for their technical help, and the Departments of Mycology, Virology and Bacteriology of the Faculty of Microbiology, Universidad de Costa Rica for their assistance. The study was funded by internal funding from Prof. Baneth's laboratory.

\section{References}

Abrego, L., Dolz, G., Romero, J., Vargas, B., Meneses, A., 2009. Detección molecular de Anaplasma platys en Costa Rica. Cienc. Vet. 27, 71-80.

Baneth, G., 2011. Perspectives on canine and feline hepatozoonosis. Vet. Parasitol. 181, 3-11.

Baneth, G., Bourdeau, P., Bourdoiseau, G., Bowman, D., Breitschwerdt, E., Capelli, G., Cardoso, L., Dantas-Torres, F., Day, M., Dedet, J.P., Dobler, G., Ferrer, L., Irwin, P., Kempf, V., Kohn, B., Lappin, M., Little, S., Maggi, R., Miró, G., Naucke, T., Oliva, G., Otranto, D., Penzhorn, B., Pfeffer, M., Roura, X., Sainz, A., Shaw, S., Shin, S., Solano-Gallego, L., Straubinger, 
R., Traub, R., Trees, A., Truyen, U., Demonceau, T., Fitzgerald, R., Gatti, D., Hostetler, J., Kilmer, B., Krieger, K., Mencke, N., Mendão, C., Mottier, L., Pachnicke, S., Rees, B., Siebert, S., Stanneck, D., Mingote, M.T., von Simson, C., Weston, S., CVBD World Forum, 2012. Vector-borne diseases-constant challenge for practicing veterinarians: recommendations from the CVBD World Forum. Parasit. Vectors 5, 55.

Barros-Battesti, D.M., Arzua, M., Bechara, G.H., 2006. Carrapatos de importância médico-veterinária da região neotropical: um guia ilustrado para identificação de espécies. Vox/ICTTD-3/Butantan, São Paulo, pp. 223.

Bermúdez, S., Miranda, R., 2011. Distribution of ectoparasites of Canis lupus familiaris L. (Carnivora: Canidae) from Panama. Rev. MVZ Cordoba 16 , 2274-2282.

Birkenheuer, A.J., Correa, M.T., Levy, M.G., Breitschwerdt, E.B., 2005. Geographic distribution of babesiosis among dogs in the United States and association with dog bites: 150 cases (2000-2003). J. Am. Vet. Med. Assoc. 227, 942-947.

Carrillo, J., Chinchilla, M., Valverde, B., Porras, O., Mora, L., 1999. Visceral leishmaniasis in Costa Rica: first case report. Clin. Infect. Dis. 29, 678-679.

Costa-Junior, L.M., Rembeck, K., Passos, L.M., Ribeiro, M.F., 2013. Factors associated with epidemiology of Anaplasma platys in dogs in rural and urban areas of Minas Gerais State, Brazil. Prev. Vet. Med. 109, 321-326.

Costa-Júnior, L.M., Zahler-Rinder, M., Ribeiro, M.F.B., Rembeck, K., Rabelo, E.M.L., Pfister, K., Passos, L.M.F., 2012. Use of a real time PCR for detecting subspecies of Babesia canis. Vet. Parasitol. 188, 160-163.

Criado-Fornelio, A., Rey-Valeiron, C., Buling, A., Barba-Carretero, J.C., Jefferies, R., Irwin, P., 2007. New advances in molecular epizootiology of canine hematic protozoa from Venezuela, Thailand and Spain. Vet. Parasitol. 144, 261-269.

Dantas-Torres, F., 2010. Biology and ecology of the brown dog tick, Rhipicephalus sanguineus. Parasit. Vectors 3, 26.

Gaunt, S., Beall, M., Stillman, B., Lorentzen, L., Diniz, P., Chandrashekar, R., Breitschwerdt, E., 2010. Experimental infection and co-infection of dogs with Anaplasma platys and Ehrlichia canis: hematologic, serologic and molecular findings. Parasit. Vectors 3, 33.

Harrus, S., Aroch, I., Lavy, E., Bark, H., 1997. Clinical manifestations of infectious canine cyclic thrombocytopenia. Vet. Rec. 141, 247-250.

Harrus, S., Baneth, G., 2005. Drivers for the emergence and re-emergence of vector-borne protozoal and bacterial diseases. Int. J. Parasitol. 35 , 1309-1318.

Harrus, S., Waner, T., 2011. Diagnosis of canine monocytotropic ehrlichiosis (Ehrlichia canis): an overview. Vet. J. 187, 292-296.

Inokuma, H., Okuda, M., Ohno, K., Shimoda, K., Onishi, T., 2002. Analysis of the 18S rRNA gene sequence of a Hepatozoon detected in two Japanese dogs. Vet. Parasitol. 106, 265-271.

Jaramillo-Antillón, O., Espinoza-Aguirre, A., Lobo-Philp, R., 2009. Estado actual de la leishmaniosis en Costa Rica. Acta Méd. Costarric. 51, $158-164$.

Kontos, V., Papadopoulos, O., French, T.W., 1991. Natural and experimental canine infections by a Greek strain of Ehrlichia platys. Vet. Clin. Pathol. 20, 101-104.

Mendoza, L., Podetti, M., Chavez, F., Zeledón, R., 1983. Visceral leishmaniasis in a dog introduced into Costa Rica. Trans. R. Soc. Trop. Med. Hyg. 77, 283-284

Otranto, D., Dantas-Torres, F., 2010. Canine and feline vector-borne diseases in Italy: current situation and perspectives. Parasit. Vectors 3, 2.

Otranto, D., Dantas-Torres, F., Breitschwerdt, E.B., 2009. Managing canine vector-borne diseases of zoonotic concern: part one. Trends Parasitol. 25, 157-163.
Otranto, D., Dantas-Torres, F., Weigl, S., Latrofa, M.S., Stanneck, D., Decaprariis, D., Capelli, G., Baneth, G., 2011. Diagnosis of Hepatozoon canis in young dogs by cytology and PCR. Parasit. Vectors 4, 55

Otranto, D., Testini, G., Dantas-Torres, F., Latrofa, M.S., Diniz, P.P., de Caprariis, D., Lia, R.P., Mencke, N., Stanneck, D., Capelli, G., Breitschwerdt, E.B., 2010. Diagnosis of canine vector-borne diseases in young dogs: a longitudinal study. J. Clin. Microbiol. 48, 3316-3324.

Parola, P., Roux, V., Camicas, J.-L., Baradji, I., Brouqui, P., Raoult, D., 2000. Detection of ehrlichiae in African ticks by polymerase chain reaction. Trans. R. Soc. Trop. Med. Hyg. 94, 707-708.

Peleg, O., Baneth, G., Eyal, O., Inbar, J., Harrus, S., 2010. Multiplex real-time qPCR for the detection of Ehrlichia canis and Babesia canis vogeli. Vet. Parasitol. 173, 292-299.

Perez, M., Bodor, M., Zhang, C., Xiong, Q., Rikihisa, Y., 2006. Human infection with Ehrlichia canis accompanied by clinical signs in Venezuela. Ann. N. Y. Acad. Sci. 1078, 110-117.

Romero, L.E., Meneses, A.I., Salazar, L., Jiménez, M., Romero, J.J., Aguiar, D.M., Labruna, M.B., Dolz, G., 2011. First isolation and molecular characterization of Ehrlichia canis in Costa Rica, Central America. Res. Vet. Sci. 91, 95-97.

Rubini, A.S., Paduan, K.S., Martins, T.F., Labruna, M.B., O’Dwyer, L.H., 2009. Acquisition and transmission of Hepatozoon canis (Apicomplexa: Hepatozoidae) by the tick Amblyomma ovale (Acari: Ixodidae). Vet. Parasitol. 164, 324-327.

Solano-Gallego, L., Baneth, G., 2011. Babesiosis in dogs and cats-expanding parasitological and clinical spectra. Vet. Parasitol. $181,48-60$.

Strauss-Ayali, D., Jaffe, C.L., Burshtain, O., Gonen, L., Baneth, G., 2004. Polymerase chain reaction using noninvasively obtained samples, for the detection of Leishmania infantum DNA in dogs. J. Infect. Dis. 189, 1729-1733.

Tabar, M.D., Altet, L., Francino, O., Sánchez, A., Ferrer, L., Roura, X., 2008. Vector-borne infections in cats: molecular study in Barcelona area (Spain). Vet. Parasitol. 151, 332-336.

Talmi-Frank, D., Nasereddin, A., Schnur, L.F., Schönian, G., Töz, S.O., Jaffe, C.L., Baneth, G., 2010. Detection and identification of old world Leishmania by high resolution melt analysis. PLoS Negl. Trop. Dis. 4, e581.

Tavares, R., Staggemeier, R., Borges, A.L.P., Rodrigues, M.T., Castelan, L.A., Vasconcelos, J., Anschau, M.E., Spalding, S.M., 2011. Molecular techniques for the study and diagnosis of parasite infection. J. Venom. Anim. Toxins Trop. Dis. 17, 239-248.

Troyo, A., Calderón-Arguedas, O., Alvarado, G., Vargas-Castro, L.E., Avendaño, A., 2012. Ectoparasites of dogs in home environments on the Caribbean slope of Costa Rica. Rev. Bras. Parasitol. Vet. 21, 179-183.

Unver, A., Perez, M., Orellana, N., Huang, H., Rikihisa, Y., 2001. Molecular and antigenic comparison of Ehrlichia canis isolates from dogs, ticks, and a human in Venezuela. J. Clin. Microbiol. 39, 2788-2793.

Vargas-Hernández, G., André, M.R., Faria, J.L., Munhoz, T.D., HernandezRodriguez, M., Machado, R.Z., Tinucci-Costa, M., 2012. Molecular and serological detection of Ehrlichia canis and Babesia vogeli in dogs in Colombia. Vet. Parasitol. 186, 254-260.

Yuasa, Y., Hsu, T.H., Chou, C.C., Huang, C.C., Huang, W.C., Chang, C.C., 2012. The comparison of spatial variation and risk factors between mosquito-borne and tick-borne diseases: Seroepidemiology of Ehrlichia canis, Anaplasma species, and Dirofilaria immitis in dogs. Comp. Immunol. Microbiol. Infect. Dis. 35, 599-606. 